\title{
PROMOSI DALAM MENINGKATKAN VOLUME PENJUALAN TINJAUAN MANAJEMEN SYARIAH
}

\author{
Yosy Arisandy dan Robby Satriawan \\ IAIN Bengkulu \\ Email:yosyarisandy@gmail.com
}

\begin{abstract}
This study aims to determine:Management reviews the increase in sales volume sharia use as a promotional marketing mixvariables.This type of research is a field research using a combined approach between Qualitative and quantitative associative. With purposive sampling technique sampling, collecting data through observation, surveys, and literature as well as data analysis techniques to test the quality of data, hypothesis testing and coefficient determinasi.Jumlah sample in this study is 30 people. The results showed that the Promotion $(X)$ significant positive effect on sales volume $(Y)$, it is shown from the results of the $t$ test with significant value $0.000<0.05$.. The amount of influence Promotion $(X)$ on sales volume $(Y)$ correlation coefficient $R=0.488(48.8 \%)$ were influenced by other variables that are not included in this study. Islam permits commerce, but with honesty in its activities including the promotion of the marketing mix.
\end{abstract}

Keywords: Promotions, sales volume, Islamic Management

Abstrak: Penelitian ini bertujuan untuk mengetahui:Tinjauan Manajemen syariah mengenai peningkatan volume penjualan menggunakan promosi sebagai variabel bauran pemasaran.Jenis penelitian adalah penelitian lapangan dengan menggunakan pendekatan gabungan antara kualitaif dan kuantitatif asosiatif.Dengan teknik sampling purposive sampling, pengumpulan data yaitu dengan observasi, survey, dan kepustakaan serta teknik analisis data dengan uji kualitas data, uji hipotesis dan koefisien determinasi.Jumlah sampel dalam penelitian ini adalah 30 orang. Hasil penelitian menunjukkan bahwa Promosi(X) berpengaruh positif signifikan terhadap volume penjualan $(Y)$, hal ini ditunjukkan dari hasil uji t dengan nilai signifikan $0,000<0,05$. Besarnya pengaruh Promosi $(X)$ terhadap volume penjualan $(Y)$ koefisien korelasi $R=$ $0,488(48,8 \%)$ sisanya dipengaruhi oleh variabel-variabel lain yang tidak termasuk dalam penelitian ini. Islam membolehkan perniagaan, namun dengan mengutamakan kejujuran dalam kegiatannya termasuk promosi dalam bauran pemasaran.

Kata Kunci: Promosi, volume penjualan, Manajemen Syariah

\section{A. PENDAHULUAN}

Penggunaan strategi promosi yang tepat pada perusahaan akan lebih mudah untuk mendapatkan konsumen. Biaya promosi dapat ditetapkan oleh perusahaan sesuai dengan kebutuhan dan anggaran yang telah ditetapkan oleh perusahaan. Yang sering terjadi dalam sebuah perusahaan adalah ketika perusahaan menggunakan biaya promosi yang tinggi, maka volume penjualan pun harusnya semakin tinggi pula. ${ }^{1}$

${ }^{1}$ Stanton, W.J. Marketing, Edisi ke-12 (New York, USA: McGraw-Hill Irwin, 2001), hlm. 231
Pada Penelitian yang telah dilakukan oleh Robby satriawan dengan judul Pengaruh Promosi terhadap Volume Penjualan Pada Kangaroo Motor Mandiri,kenaikan biaya promosi yang dikeluarkan perusahaan tiap tahunnya tidak diiringi dengan peningkatan volume penjualan pada perusahaan.

\section{B. PEMBAHASAN}

\section{Penjualan}

Penjualan merupakan salah satu fungsi pemasaran yang sangat penting dan menentukan bagi perusahaan dalam mencapai tujuan perusahaan yaitu memperoleh laba untuk menjaga 
kelangsungan hidup perusahaan.

Sebenarnya pengertian penjualan sangat luas, beberapa para ahli mengemukakan tentang definisi penjualan antara lain:

Menurut Moekijat dalam buku Kamus istilah ekonomi menyatakan bahwa: "Selling : melakukan penjualan adalah suatu kegiatan yang ditujukan untuk mencari pembeli, mempengaruhi dan memberikan petunjuk agar pembeli dapat menyesuaikan kebutuhannya dengan produk yang ditawarkan serta mengadakan perjanjian mengenai harga yang menguntungkan bagi kedua belah pihak".

Pengertian penjualan adalahproses sosial manajerial dimana individu dan kelompok mendapatkan apa yang mereka butuhkan dan inginkan, menciptakan, menawarkan, dan mempertukarkan produk yang bernilai dengan pihak lain”. Lanjutan yang menjelaskan bahwa penjualan (sales) adalah sejumlah uang yang dibebankan kepada pembeli atas barang atau jasa yang dijual. $^{2}$

Dari penjelasan diatas dapat disimpulkan bahwa promosi adalah suatu proses pembuatan dan cara untuk mempengaruhi pribadi agar terjadi pembelian (penyerahan) barang atau jasa yang ditawarkan berdasarkan harga yang telah disepakati oleh kedua belah pihak yang terkait didalam kegiatan tersebut.

a. Faktor-Faktor Mempengaruhi Penjualan

Dalam praktek, kegiatan penjualan ini dipengaruhi oleh beberapa faktor yaitu: ${ }^{3}$ kondisi dan Kemampuan Pasar yang mana penjual harus dapat meyakinkan pembeli agar berhasil mencapai sasaran penjualan yang diharapkan untuk maksud tertentu, penjual harus memahami beberapa masalah penting yang sangat berkaitan yaitu jenis dan karakteristik barang yang ditawarkan, harga Produk, syarat penjualan seperti pembayaran, pengantaran, garansi, dan sebagainya.

Faktor selanjutnya kondisi Pasar. Hal yang harus diperhatikan pada kondisi pasar antara lain adalah jenis pasarnya, apakah pasar konsumen, pasar industri, pasar pemerintah atau pasar Internasional, kelompok pembeli dan segmen pasarnya, daya beli, frekuensi pembeliannya, keinginan dan kebutuhan. Faktor selanjutnya modal. Apakah modal kerja perusahaan mampu untuk mencapai target penjualan yang kedua (Yogyakarta: Andi, 2004), hlm. 90 
dianggarkan seperti untuk kemampuan untuk membiayai penelitian pasar yang dilakukan, kemampuan membiayai usaha-usaha untuk mencapai target penjualan, kemampuan membeli bahan mentah untuk dapat memenuhi target penjualan, kondisi organisasi perusahaan. Pada perusahaan besar, biasanya masalah penjualan ditangani oleh bagian penjualan. Lain halnya dengan perusahaan kecil, dimana masalah penjualan ditangani oleh orang yang juga melakukan fungsi-fungsi lain.

\section{b. Fungsi dan Tujuan Penjualan}

Fungsi penjualan meliputi aktivitas-aktivitas yang dilakukan oleh penjual untuk merealisasikan penjualan seperti menciptakan permintaan, mencari pembeli, memberikan saran-saran, membicarakan syarat-syarat penjualan, dan memindahkan hak milik.

Pada umumnya, para pengusaha mempunyai tujuan yaitu mendapatkan laba tertentu (semaksimal mungkin), dan mempertahankan atau bahkan berusaha meningkatkannya untuk jangka waktu yang lama. Tujuan tersebut dapat direalisasi apabila penjualan dapat dilaksanakan seperti yang telah direncanakan. Perusahaan pada umumnya mempunyai tiga tujuan umum dalam penjualan, yaitumencapai volume penjualan tertentu, mendapatkan laba tertentu, menunjang pertumbuhan perusahaan.

\section{c. Volume Penjualan}

Dari penjelasan mengenai penjualan, penjualan selalu dikaitkan dengan istilah penjualan dan volume penjualan. Besar kecilnya hasil penjualan dipengaruhi oleh jumlah produk yang terjual.Volume Penjualan adalah total penjualan yang di dapat dari komoditas yang diperdagangkan dalam suatu masa tertentu. Sedangkan pengertian Volume Penjualan menurut Abdullah, bahwa Volume penjualan adalah jumlah unit yang terjual dari unit produksi suatu pemindahan dari pihak produksi ke pihak konsumen, dan tetap pada suatu periode tertentu".

Menurut Alimiyah \& Padji, menyatakan bahwa Jumlah penjualan yang berhasil dicapai atau ingin dicapai oleh suatu perusahaan pada periode tertentu.

Berdasarkan dari pengertianpengertian di atas dapat ditarik kesimpulan bahwa volume penjualan merupakan hasil dari kegiatan penjualan yang dilakukan oleh 
perusahaan dalam usahanya

mencapai sasaran yaitu

memaksimalkan laba.

Faktor yang sangat penting dalam mempengaruhi volume penjualan adalah saluran distribusi yang bertujuan untuk melihat peluang pasar apakah dapat memberikan laba yang maksimun. Secara umum mata rantai saluran distribusi yang semakin luas akan menimbulkan biaya yang lebih besar, tetapi semakin luasnya saluran distribusi maka produk perusahaan akan semakin dikenal oleh mayarakat luas dan mendorong naiknya angka penjualan yang akhirnya berdampak pada peningkatan volume penjualan ${ }^{4}$

\section{d. Pengaruh Promosi terhadap} Volume Penjualan

Pada bauran pemasaran salah satu variabel yang penting ialah promosi.Promosi merupakan salah satu factor yang penting dalam menentukan keberhasilan dalam perusahaan. Sebaik apapun produk yang dibuat tapi konsumen belum kenal maka produk tersebut tak akan dibeli, maka diperlukan promosi untuk mengenalkan produk terhadap konsumen sehingga konsumen berminat untuk membeli. Karena

${ }^{4}$ Pakpahan, Efendi,Volume Penjualan, (Jakarta:PT. Bina Intitama Sejahtera, 2009),hlm.59 kegiatan promosi adalah suatu bentuk kegiatan komunikasi pemasaran yang berusaha menyebarkan informasi, mempengaruhi, mengingatkan pasar sasaran agar bersedia menerima, membeli, dan loyal pada produk yang ditawarkan oleh perusahaan yang bersangkutan. Promosi adalah mengkomunikasikan keunggulan produk dan membujuk sasaran untuk dapat membeli sebuah produkdan jasa yang ditawarkan.Kegiatan tersebut tidak terlepas dari biaya yang dikeluarkan demi mencapai hasil yang efektif, oleh karena itu perusahaan harus menganggarkan biaya promosi dengan sebaik mungkin untuk menghindari terjadinya kerugian dengan menyesuaikan bentuk promosi yang dilakukan. $^{5}$

Promosi merupakan salah satu variabel dalam bauran pemasaran yang sangat penting dilaksanakan oleh perusahaan dalam memasarkan produk guna meningkatkan volume penjualan. Kegiatan promosi bukan saja berfungsi sebagai alat komunikasi antara perusahaan dengan konsumen, melainkan juga sebagai alat untuk mempengaruhi

${ }^{5}$ Abdullah, Faisal M, Dasar-dasar Manajemen Keuangan, (Jawa Timur: UniversitasMuhammadiyah Malang, 2001), hlm. 89 
konsumen dalam kegiatan pembelian atau penggunaan produk sesuai dengan kebutuhan dan keinginannya.Kegiatan promosi dan biaya promosi berhubungan erat dan harus diperhatikan. Penerapan kegiatan promosi yang dilakukan perusahaan meliputi periklanan (advertising), promosi penjualan (sales promotion) penjualan perorangan (personal selling), dan publisitas (publicity).Kegiatan promosi ini diharapkan dapat mempertahankan ketenaran merek (brand image) dalam menggunakan strategi yang tepat. ${ }^{6}$

Ada 3 faktor dasar yang merupakan titik berat dari konsep pemasaran yaituseluruh perencanaan dan kegiatan perusahaan harus berorientasi pada konsumen/pasar, volume penjulan yang mengutungkan harus menjadi tujuan perusahaan dan seluruh kegiatan pemasaran dalam perusahaan harus dikoordinasikan dan diintegrasikan secara organisasi. ${ }^{7}$

Definisi tersebut mempunyai konsekuensi bahwa semua kegiatan perusahaan tersebut yang meliputi produksi, teknik, keuangan dan

${ }^{6}$ Abdullah, Faisal M. Dasar-dasar Manajemen Keuangan, (Jawa Timur: UniversitasMuhammadiyah Malang, 2001), hlm. 89

${ }^{7}$ Basu Swastha, dan Irawan, Manajemen Pemasaran Moderen, (Jakarta: FE UI,2007), hlm. 78 pemasaran harus diarahkan pada usaha mengetahui kebutuhan pembeli, kemudian memuaskan kebutuhan tersebut dengan mendapatkan laba yang layak dalam jangka panjang.

Konsep marketing adalah "Sebuah falsafah bisnis yang menyatakan bahwa konsumen merupakan syarat ekonomi dan sosial bagi kelangsungan hidup peruasahaan". 8

\section{Promosi}

Promosi merupakan kegiatan yang paling ampuh untuk menarik dan mempertahankan konsumen. Salah satu tujuan promosi adalah mengiformasikan segala jenis produk yang ditawarkan dan berusaha untuk menarik calon nasabah yang baru. Kemudian promosi juga berfungsi mengingatkan nasabah akan produk, promosi juga ikut mempengaruhi nasabah untuk membeli dan dan akhirnya promosi juga akan meningkatkan citra bank di mata nasabahnya ${ }^{9}$

Promosi merupakan salah satu variabel marketing mix yang digunakan oleh perusahaan untuk mengadakan komunikasi dengan pasarnya. Promosi juga sering dikatakan sebagai "proses

\footnotetext{
${ }^{8}$ Ika dan Abdul, Prinsip Dasar Ekomoni Islam.(Jakarta: Prenada Media Group, 2014), hlm. 44

${ }^{9}$ Kasmir, Bank dan Lembaga Keuangan Lainnya.(Jakarta: PT Raja Grafindo, 2005), hlm. 207
} 
berlanjut karena dapat menimbulkan rangkaian kegiatan lanjutan yaitu arus informasi persuasi satu arah yang dibuat untuk mengarahkan seseorang atau organisasi kepada tindakan yang menciptakan pertukaran didalam pemasaran". ${ }^{10}$ Dari definisi tersebut dapat disimpulkan bahwa setiap perusahaan dalam usaha meningkatkan kegiatan promosinya dapat menggunakan komunikasi persuasif yang diarahkan kepada usaha-usaha yang menciptakan pertukaran antara perusahaan dan para konsumen atau pembeli.

\section{a. Tujuan Promosi}

Ada beberapa tujuan dari dilakukannya promosi, tujuan promosi diantaranya $:{ }^{11}$ modifikasi tingkah laku. Pasar merupakan tempat pertemuan orang-orang yang hendak melakukan suatu pertukaran di mana orang-orangnya terdiri atas berbagai macam tingkah laku yang satu sama lain saling berbeda. Demikian juga pendapat mereka mengenai suatu barang dan jasa, selera, keinginan, motivasi, dan kesetiaannya terhadap barang dan jasa tersebut saling berbeda.Dengan

${ }^{10}$ Swastha, Basu dan T. Hani Handoko, Manajemen Pemasaran, Analisa Perilaku Konsumen, edisi pertama, cetakan keempat (Yogyakarta: Penerbit BPFE, 2004), hlm. 220

${ }^{11}$ Rangkuti. Strategi Promosi Yang Kreatif, edisi pertama, cetakan pertama. (Jakarta: Gramedia Pustaka Utama, 2009), hlm. 106 demikian, tujuan dari ini adalah berusaha untuk mengubah tingkah laku dan pendapat individu tersebut, dari tidak menerima suatu produk menjadi setia terhadap produk.

Kemudian tujuan selanjutnya memberitahu. Kegiatan promosi yang ditujukan untuk memberikan informasi kepada pasar yang dituju tentang pemasaran perusahaan, mengenai produk tersebut berkaitan dengan harga, kualitas, syarat pembeli, kegunaan, keistimewaan, dan lain sebagainya. Promosi yang bersifat informasi ini umumnya lebih disukai dan dilakukanpada tahaptahap awal dalam siklus kehidupan produk.

Hal ini merupakan masalah penting untuk meningkatkan permintaan primer sebab pada tahap ini sebagian orang tidak akan tertarik untuk memilih dan membeli barang dan jasa sebelum mereka mengetahui produk tersebut serta kegunaannya dan lain sebagainya. Promosi yang bersifat informasi ini dapat membantu konsumen dalam mengambil keputusan untuk membeli.

Lanjut, tujuannya membujuk. Promosi yang bersifat membujuk atau persuasif ini pada umumnya kurang disenangi oleh sebagian 
masyarakat.Tetapi kenyataannya sekarang imi banyak muncul justru adalah promosi tersebut.Promosi seperti itu terutama untuk mendorong pembeli.Perusahaan tidak ingin memperoleh tanggapan secepatnya, tetapi lebih mengutamakan untuk menciptakan kesan positif.Hal ini dimaksudkan agar promosi dapat memberi pengaruh dalam waktu yang lama terhadap perilaku pembeli. Promosi yang bersifat membujuk ini akan menjadi dominan jika produksi yang bersangkutan mulai memasuki tahap pertumbuhan dalam siklus kehidupan produk tersebut.

Tujuan lainnya mengingatkan. Promosi yang bersifat mengingatkan ini dilakukan terutama untuk mempertahankan merek produk di hati masyarakat dan dilakukan selama tahap kedewasaan dalam siklus kehidupan produk.Ini berarti perusahaan berusaha memperhatikan untuk mempertahankan pembeli yang ada, sebab pembeli tidak hanya sekali saja melakukan transaksi, melainkan harus berlangsung secara terus-menerus. $^{12}$

\section{b. Bentuk - bentuk Promosi}

\footnotetext{
${ }^{12}$ Daryanto.Sari Kuliah Menajemen Pemasaran.(Bandung: PT Sarana Tutorial Nurani Sejahtera, 2014), hlm. 95
}

Berikut adalah macam macam bentuk promosi advertising. Periklanan didefinisikan sebagai bentuk penyajian dan promosi ide, barang atau jasa secara nonpersonal oleh suatu sponsor tertentu yang memerlukan pembayaran. Secara garis besar Advertising adalah bentuk promosi non personal dengan menggunakan berbagai media yang ditujukan untuk merangsang pembelian.Iklan memiliki beberapa karakteristik, antara lain adalah Suatu bentuk komunikasi yang berbayar, nonpersonal komunikasi, menggunakan media massa sebagai massifikasi pesan, menggunakan sponsor yang teridentifikasi, bersifat mempersuasi khalayak dan bertujuan untuk meraih audiens sebanyakbanyaknya. $^{13}$

\section{c. Biaya Promosi}

Biaya adalah suatu pengorbanan yang dapat mengurangi kas atau harta lainnya untuk mencapai tujuan, baik yang dapat dibebankan pada saat ini maupun pada saat yang akan datang. ${ }^{14}$ Biaya adalah pengorbanan sumber daya untuk mencapai suatu tujuan tertentu. Promosi adalah kegiatan memberitahukan dan

${ }^{13}$ Kotler, Philip. Manajemen Pemasaran, Analisa perencanaan, Implementasi dan control, Edisi Kesembilan (Jakarta: Prehallindo, 2002),hlm. 658

${ }^{14}$ Mursyidi .Akuntansi Biaya, Bandung: Penerbit Refika Aditama, 2008, hlm. 45 
mengkomunikasikan kepada

masyarakat tentang keberadaan

produk kemanfaatan, keunggulan, atribut-atribut yang dimiliki, harga, dimana dan cara memperolehnya

Biaya Promosiadalah pengorbanan sumber ekonomi yang dapat diukur dalam satuan uang yang telah terjadi secara potensial untuk mencapai tujuan tertentu agar penyampaian informasi dari penjual ke pembeli dapat mempengaruhi sikap dan tingkah laku pembeli. ${ }^{15}$ Biaya merupakan komponen penting yang juga mendapat perhatian. Kelangsungan hidup suatu perusahaan terkadang ditentukan oleh bagaimana perusahaan mengelola biaya-biaya yang ada. Biaya dalam lembaga nirlaba ditentukan oleh besarnya pendapatan atau penghasilan yang akan diperoleh diperiode akan datang. Sementara itu, penghasilan itu sendiri ditentukan oleh berapa banyak komitmen donasi dan penghasilan tidak terikat lain yang merupakan usaha sendiri dari perusahaan. Dengan kata lain, biaya pada perusahaan harus memiliki fleksibilitas dan kelenturan yang jauh

${ }^{15}$ Nainggolan, Pengaruh Audit Internal Terhadap Kinerja Perusahaan. Jurnal Ilmiah. 2007 lebih tinggi dibandingkan biaya pada perusahaan komersial.

Pada perusahaan komersial, biaya merupakan komponen yang dikeluarkan lebih dahulu untuk menghasilkan pendapatan. Sepanjang biaya yang sudah di keluarkan dan proses produksi sudah berjalan, bisa dipastikan pendapatan akan diperoleh. Tinggal bagaiman cara mengelola pendapatan agar dapat menutupi biaya yang timbul dan menghasilkan laba.

\section{d. Pengaruh Promosi terhadap} Volume Penjualan

Iklan (Advertising) adalah "Bentuk presentasi, promosi, gagasan, barang dan jasa non pribadi yang dibayar oleh sponsor tertentu".Perangkat bauran promosi yang selanjutnya yaitu penjualan perorangan. Penjualan perorangan adalah "suatu proses membantu dan membujuk satu atau lebih calon konsumen untuk membeli barang atau jasa untuk bertindak sesuai ide tertentu dengan menggunakan presentasi oral (komunikasi tatap muka)". Perangkat bauran promosi yang selanjutnya yaitu promosi penjualan, dalam pemasaran promosi penjualan merupakan salah satu dari bauran promosi yang memiliki peran penting dalam rangka menumbuhkan 
minat konsumen terhadap suatu produk.Promosi penjualan merupakan salah satu bentuk khusus komunikasi untuk memenuhi fungsi pemasaran.Promosi penjualan itu terdiri dari bermacam-macam alat insentif, kebanyakan didesain untuk kepentingan jangka pendek untuk merangsangdengan cepat para konsumen agar melakukan pembelian produk tertentu melalui perdagangan.Periklanan menawarkan sebuah alasan untuk membeli sedangkan promosi penjualan menawarkan sebuah rangsangan untuk membeli.

Semua organisasi, baik yang berbentuk badan usaha swasta, badan yang bersifat publik ataupun lembaga-lembaga sosial kemasyarakatan, tentu mempunyai suatu tujuan sendiri-sendiri yang merupakan motivasi dari pendiriannya. ${ }^{16}$

$$
\text { Proses-proses manajemen, }
$$
termasuk manajemen syariah. ${ }^{17} \mathrm{Pada}$ dasarnya adalah perencanaan segala sesuatu secara mantap untuk melahirkan keyakinan yang berdampak pada melakukan sesuatu

${ }^{16}$ Zainul Arifin, Dasar-dasar Manajemen Bank Syariah (Jakarta: Alvabet, 2005), hlm. 97.

${ }^{17}$ Sofyan Syafri Harahap,Akuntansi Pengawasan dan Manajemen dalam Perspektif Islam (Jakarta: Fakultas Ekonomi UniversitasTrisakti, 1992), hlm. 126 sesuai dengan aturan serta memiliki manfaat. ${ }^{18}$ Fungsi perencanaan meliputi strategi, dan strategi merupakan bagian yang tidak terpisahkan dengan sutau bisnis atau perusahaan.Demikian juga dalam pemasaran dibutuhkan suatu strategi, terlebih lagi dalam dunia bisnis yang penuh persaingan, maka strategi sangat penting yang kemudian disebut strategi pemasaran dengan melakukan promosi untuk meningkatkan volume penjualan. ${ }^{19}$

Tingkat persaingan dalam dunia bisnis menuntut setiap pemasar untuk mampu melaksanakan kegiatan pemasarannya dengan lebih efektif dan efisien.Kegiatan pemasaran tersebut membutuhkan sebuah konsep pemasaran yang mendasar sesuai dengan kepentingan pemasar dan kebutuhan serta keinginan pelanggan.Dalam hal ini, pemasaran Islami memiliki posisi yang sangat strategis, karena promosi Islami merupakan salah satu strategi pemasaran yang didasarkan pada AlQur'an dan Sunah Rasulullah SAW. Pemasaran Islami merupakan sebuah disiplin bisnis strategis yang

${ }^{18}$ Didin Hafidhuddin dan Hendri Tanjung, Manajemen Syariah dalam Praktek (Jakarta: Gema insane, 2003), hlm. 3

${ }^{19}$ M. Ma'ruf Abdullah, Manajemen Berbasis Syariah (Yogyakarta: Aswaja Pressindo, 2014), hlm. 144 
mengarahkan proses penciptaan, penawaran, dan perubahan values (nilai) dari satu inisiator (pemrakarsa) kepada stakeholdersnya, yang dalam keseluruhan prosesnya sesuai dengan akad serta prinsip-prinsip Islam dan muamalah dalam Islam.

Setiap perusahaan baik itu beroperasi pada promosi untuk optimalisasi dalam mencapai tujuannya.Promosi yang kompleks ini selalu berubah-ubah sebagai konsekuensi dari perubahan sosial. Bagi perusahaan perubahan lingkungan dapat menjadi tantangan yang baru bagi pemasaran usaha, sehingga hal ini memerlukan tanggapan dan cara penyelesaian yang baru pula atau sebaliknya dapat berubah menjadi peluang atau kesempatan mengembangkan usaha. Dengan demikian promosi dalam sebuah perusahaan tidak dapat dilakukan hanya sekali proses saja, namun butuh proses panjang untuk membuat strategi pemasaran yang sesuai dengan perusahaan tersebut.

Hal yang paling mendasar dan diperlukan dalam promosi adalah bagaimana cara dan upaya untuk menarik minat masyarakat/calon konsumen agarmau berbelanja agar dapat bertahan ataupun menambah jumlah pembeli/konsumen di tempat tersebut. Dalam kegiatan promosi perlu lebih dari sekedar pengembangan produk, penetapan harga dan membuat produk yang ditawarkan dapat dijangkau oleh konsumen.Pemberian informasi mengenai produk atau jasa yang ditawarkan tersebut melalui kegiatan promosi.

\section{Promosi Dalam Meningkatkan} Volume Penjualan Tinjauan Manajemen Syariah

Pada penelitian yang dilakukan oleh Robby Satriawan (2017) dengan judul Pengaruh Promosi terhadap Volume Penjualan Pada Kangaroo Motor Mandiri. Hasil penelitian menunjukkan bahwa Promosi(X) berpengaruh positif signifikan terhadap volume penjualan (Y) pada Kangaroo Motor Mandiri, hal ini ditunjukkan dari hasil uji t dengan nilai signifikan 0,000 $<0,05$. Besarnya pengaruh Promosi $(\mathrm{X})$ terhadap volume penjualan(Y) koefisien korelasi $\mathrm{R}=0,488$ (48,8\%).

Hasil penelitian menunjukkan bahwa biaya promosi berpengaruh signifikan terhadap volume penjualanmobil. Dilihat dari hasil perhitungan SPSS variabel biaya promosi (X) dan volume penjualan (Y), secara bersama-sama memberikan sumbangan sebesar 0,905 dalam 
mempengaruhi volume penjualan pada Kangaroo Motor Mandiri.

Hasil penelitian ini relevan dengan penelitian yang dilakukan oleh Susanti (2015) dengan judul Pengaruh Biaya Promosi terhadap volume penjualan pada PT. MNC BMY Visien Bengkulu.Hasil penelitian menujukkan ada pengaruh yang signifikan antara Biaya Promosi terhadap volume penjualan pada PT. MNC BMY Visien Bengkulu.Berdasarkan nilai yang didapat, maka besar kontribusi variabel promosi terhadap variabel penjualan adalah $77,44 \%$.

Hal ini sejalan dengan teori yang dijelaskan oleh Swastha (2007: 175), salah satu faktor yang mempengaruhi volum penjualan adalah faktor lain yaitu biaya promosi yang terdiri dari periklanan, peragaan, kampanye, dan pemberian hadiah sering mempengaruhi penjualan karena diharapkan dengan adanya faktor-faktor tersebut pembeli akan kembali membeli lagi barang yang sama.

Dari Penelitian tersebut dapat kita ketahui bahwa promosi memiliki pengaruh terhadap peningkatan volume penjualan, yang akhirnya berujung pada keuntungan perusahaan atau usaha. Keuntungan yang menjanjikan hendaknya tidak membuat pelaku usaha melakukan hal yang tidak sesuai dengan etika tetapi selalu mengutamakan kejujuran.

Agama Islam merupakan agama rahmatan lil alamin, yang mengajarkan kepada kita untuk selalu menegakkan kebenaran dan mengedepankan kejujuran dalam hal apapun, termasuk dalam berniaga. Nabi Muhammad SAW terkenal karena kejujurannya dalam berniaga, sehingga beliau dijulukin $\mathrm{Al}$ amin.Beliau mengajarkan bahwa pekerjaan berniaga merupakan pekerjaan yang mulia dan menjadikan kesejahteraan, dengan cara pemasaran yang baik.

Pemasaran mempunyai peranan yang sangat penting untuk keberhasilan perusahaan umumnya dan pada bidang pemasaran khususnya.Di samping itu pemasaran yang diterapkan harus ditinjau dan dikembangkan sesuai dengan perkembangan pasar dan lingkungan pasar tersebut. Dengan demikian pemasaran harus dapat memberikan gambaran yang jelas dan terarah tentang apa yang dilakukan perusahaan dalam menggunakan setiap kesempatan atau paduan pada beberapa sasaran pasar. ${ }^{20}$ Persaingan yang ketat antar perusahaan membuat pengusaha harus menetapkan strategi pemasaran bagi usahanya.Adapun ayat al Quran

${ }^{20}$ Fandi Tjiptono, Strategi Pemasaran, edisi kedua (Yogyakarta: Andi, 2004), hlm. 332 
yang berhubungan dengan persaingan

bisnis sebagai berikut:

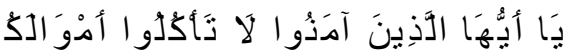

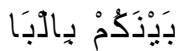

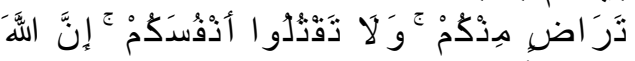

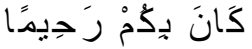

"Hai orang-orang yang beriman, janganlah kamu saling memakan harta sesamamu dengan jalan yang batil, kecuali dengan jalan perniagaan yang Berlaku dengan suka sama-suka di antara kamu.dan janganlah kamu membunuh dirimu. Sesungguhnya Allah adalah Maha Penyayang kepadamu" ${ }^{21}$ (QS An-nisaa': 29)

Ayat di atas menjadi bukti bahwa Allah melarang persaingan bisnis yang menjatuhkan orang lain. Karena hal itu tergolong ke dalam mengambil harta sesama dengan jalan kebatilan. Melihat pentingnya strategi pemasaran terhadap peningkatan volume penjualan perusahaan.

Dari hasil penelitian terdahulu didapat bahwa terdapat pengaruh antara promosi terhadap peningkatan volume penjualan. Namun promosi yang dilakukan hendaknya sesuai dengan kaidah yang berlaku, sehingga pihak konsumen tidak merasa tertipu atas produk yang didapatnya.

$$
\text { Manajemen syariah telah }
$$
menjelaskan mengenai karakteristik pemasaran Islami adalah Ketuhanan. Theistis atau ketuhanan atau rabbaniyah adalah satu keyakinan yang bulat,

${ }^{21}$ DepartemenAgama $\quad$ RI, $\quad A l$ Qur' andanTerjemahnya, (Semarang: CV.ThohaPutra, 2009) bahwa semua gerak-gerik manusia selalu berada di bawah pengawasan Allah SWT. Oleh sebabitu, semua insan harus berperilaku sebaik mungkin, tidak berperilaku licik, sukamenipu, mencuri milik orang lain suka memakan harta orang lain dengan jalanyang batil dan sebagainya. Kondisi tersebut sangat diyakini oleh umat Muslim,sehingga menjadi pegangan hidup, tidak tergoyahkan.Nilai Rabbaniyah tersebutmelekat atau menjadi darah daging dalam pribadi setiap Muslim, sehingga dapatmengerem perbuatanperbuatan tercela dalam dunia bisnis. Promosi yang dilakukan hendaknya berperilaku sebaik mungkin, tidak berperilaku licik, sukamenipu, mencuri milik orang lain suka memakan harta orang lain dengan jalanyang batil. ${ }^{22}$

Selain itu, Etis (akhlak). Etis atau akhlaqiah artinya semua perilaku berjalan di atas normaetika yang berlaku umum. Etika adalah kata hati, dan kata hati ini adalah katayang sebenarnya, "the will of God", tidak bisa dibohongi. Seorang penipu yangmengoplos barang, menimbun barang, mengambil harta orang lain dengan jalan yang bathil pasti hati kecilnya berkata lain, tapi karena rayuan setan maka ia tergoda berbuat curang,

${ }^{22}$ Didin Hafidhuddin dan Hendri Tanjung, Manajemen Syariah dalam Praktek..., hlm. 3 
ini artinya ia melanggar etika, ia tidak menuruti apa kata hati yang sebenarnya. Oleh sebab itu, hal ini menjadi panduan para marketing Islami untuk selalu memelihara setiap tutur kata, perilaku dalam berhubungan bisnis dengan siapa saja, konsumen, penyalur, toko, pemasok ataupun saingannya. Promosi yang dilakukan oleh pihak perusahaan hendaknya sesuai dengan konsep etis (akhlak) artinya tidak berbuat curang, yakni ia melanggar etika, ia tidak menuruti apa kata hati yang sebenarnya ${ }^{23}$

Kemudian, Realistis. Realistis atau al-waqiiyyah yang artinya sesuai dengan kenyataan, jangan menjurus kepada kebohongan. Semua transaksi yang mengada-ada apalagi yang dilakukan harus berlandasan pada realita, tidak membeda-bedakan orang, suku,warna kulit. Semua tindakan penuh dengan kejujuran. Bahkan ajaran Rasulullah SAW tentang sifat realistis ini ialah jika anda menjual barang ada cacatnya, maka katakan kepada calon pembeli, bahwa barang ini ada sedikit cacat. Jika pembeli setelah diberitahu masih tetap ingin memiliki barang tersebut, itu lebih baik. ${ }^{24}$ Tidak boleh anda bersumpah, bahwa barang

\footnotetext{
${ }^{23}$ Didin Hafidhuddin dan Hendri Tanjung, Manajemen Syariah dalam Praktek..., hlm. 4

${ }^{24}$ Didin Hafidhuddin dan Hendri Tanjung, Manajemen Syariah dalam Praktek..., hlm. 4
}

tersebut betul-betul baik dan sempurna, padahal ada cacatnya. Bahan makanan yang basah jangan disimpan dibawah, tapi naikkan ke atas agar dapat dilihat oleh pembeli. Demikian mulianya ajaran Rasulullah SAW sangat realistis, jangan sekali-kali mengelabui orang, iniharus diikuti oleh umatnya.

Selanjtnya, Humanistis. Humanistis atau al-insaniyah yang artinya berperikemanusiaan, hormat menghormati sesama. Promosi berusaha membuat kehidupan menjadi lebih baik. Jangan sampai kegiatan pemasaran malah sebaliknya merusak tatanan hidup di masyarakat, menjadikan kehidupan bermasyarakat terganggu, seperti hidupnya gerombolan hewan, tidak ada aturandan yang kuat yang berkuasa. Juga dari segi pemasar sendiri, jangan sampai menjadi manusia serakah, mau menguasai segalanya, menindas dan merugikan orang lain. ${ }^{25}$

Tujuan analisis volume penjualan adalah agar perusahaan dapat mengetahui keefektifan penggunaan biaya promosi tersebut sehingga perusahaan dapat terus meningkatkan kegiatan promosi dan mengendalikan biaya promosi yang dikeluarkan untuk kegiatan promosi tersebut. Jadi dapat disimpulkan biaya-biaya yang dikeluarkan oleh perusahaan untuk 
kegiatan promosi berguna untuk menjual atau memperkenalkan produknya kepada para konsumen. Karena ada kaitannya dengan jumlah hasil penjualan yang akan diperoleh perusahaan dari aktivitas promosi tersebut.

\section{KESIMPULAN}

1. Promosi berpengaruh positif signifikan terhadap volume penjualandibuktikan dengan hasil uji $t$ dengan nilai signifikan 0,000 < 0,05dibuktikan pada penelitian Pengaruh Promosi terhadap Volume Penjualan Pada Kangaroo Motor Mandiri.

2. Besarnya pengaruh Promosi (X) terhadap volume penjualan $(\mathrm{Y})$ koefisien korelasi $\mathrm{R}=0,488(48,8 \%)$ sisanya dipengaruh oleh variabelvariabel lain yang tidak termasuk dalam penelitian ini.

3. Islam membolehkan perniagaan, namun dengan mengutamakan kejujuran dalam kegiatannya termasuk promosi dalam

\section{DAFTAR PUSTAKA}

Abdullah, Faisal M. Dasar-dasar Manajemen Keuangan. Jawa

Timur:UniversitasMuhammadiyah Malang. 2001

Basu Swastha, dan Irawan, Manajemen Pemasaran Moderen. Jakarta: FE UI.2007

\begin{tabular}{ccrl} 
Daryanto.Sari & Kuliah & \multicolumn{2}{r}{ Menajemen } \\
Pemasaran.Bandung: & PT & Sarana \\
Tutorial Nurani Sejahtera. 2014 &
\end{tabular}

DepartemenAgamaRI, $A l$ -

Qur' andanTerjemahnya. Semarang:

CV.ThohaPutra. 2009

Hafidhuddin ,Didin dan Hendri Tanjung, Manajemen Syariah dalam Praktek. Jakarta: Gema insane. 2003

Ika dan Abdul.Prinsip Dasar Ekomoni Islam. Jakarta: Prenada Media Group. 2014

Kasmir.Bank dan Lembaga Keuangan Lainnya. Jakarta: PT Raja Grafindo, 2005

Kotler, Philip diterjemahkan oleh A.B Susanto.Manajemen Pemasaran Indonesia. Jakarta: Salemba Empat. 2000

Kotler, Philip. Manajemen Pemasaran, Analisa perencanaan, Implementasi dan control, Edisi Kesembilan.Jakarta: Prehallindo. 2002

M. Ma'ruf Abdullah, Manajemen Berbasis Syariah. Yogyakarta: Aswaja Pressindo. 2014

Mursyidi ,Akuntansi Biaya. Bandung : Penerbit Refika Aditama. 2008

Nainggolan, Pengaruh Audit Internal Terhadap Kinerja Perusahaan. Jurnal Ilmiah. 2007

Pakpahan, Efendi. Volume Penjualan.Jakarta:PT. Bina Intitama Sejahtera. 2009

Rangkuti. Strategi Promosi Yang Kreatif, edisi pertama, cetakan pertama. Jakarta: Gramedia Pustaka Utama. 2009

Sofyan Syafri Harahap,Akuntansi Pengawasan dan Manajemen dalam Perspektif Islam .Jakarta: Fakultas Ekonomi UniversitasTrisakti. 1992

Stanton, W.J. Marketing, Edisi ke-12 New York, USA: McGraw-Hill Irwin. 2001

Swastha, Basu dan T. Hani Handoko, Manajemen Pemasaran, Analisa Perilaku Konsumen, edisi pertama, cetakan keempat. Yogyakarta: Penerbit BPFE, 2004 
Tjiptono,Fandy. Strategi Pemasaran, edisi kedua.Yogyakarta: Andi. 2004

Zainul Arifin, Dasar-dasar Manajemen Bank

Syariah.Jakarta: Alvabet. 2005 